DOI: $10.1590 / 1089-6891 v 20 \mathrm{e}-55428$

VETERINARY MEDICINE

\title{
ORIGIN AND ANTIMERIC DISTRIBUTION OF THE OBTURATOR NERVES IN THE NEW ZEALAND RABBITS
}

\section{ORIGEM E DISTRIBUIÇÃO ANTIMÉRICA DOS NERVOS OBTURATÓRIOS EM COELHOS NOVA ZELÂNDIA}

\author{
Renata Medeiros do Nascimento ${ }^{1}$ ORCID - http://orcid.org/0000-0002-0473-9545 \\ Thais Mattos Estruc ${ }^{1}$ ORCID - http://orcid.org/0000-0003-4559-3746 \\ Jorge Luiz Alves Pereira² ORCID - http://orcid.org/0000-0002-6314-666X \\ Erick Candiota Souza ${ }^{3}$ ORCID - http://orcid.org/0000-0001-6211-5944 \\ Paulo Souza Junior ${ }^{3}$ ORCID - http://orcid.org/0000-0002-6488-6491 \\ Marcelo Abidu-Figueiredo ${ }^{1 *}$ ORCID - http://orcid.org/0000-0003-2251-171X \\ ${ }^{1}$ Universidade Federal Rural do Rio de Janeiro, Seropédica, RJ, Brazil \\ ${ }^{2}$ Universidade Estácio de Sá, Rio de Janeiro, RJ, Brazil. \\ 3Universidade Federal do Pampa, Uruguaiana, RS, Brazil. \\ "Correspondent author - marceloabidu@gmail.com
}

\begin{abstract}
New Zealand rabbits are widely used as experimental models and represent an important casuistic in veterinary practices. The musculoskeletal conformation of rabbits frequently leads to the occurrence of lumbosacral lesions with neural involvement. In order to contribute to the comparative anatomy and the understanding of these lesions, the origin and distribution of the obturator nerves of $30 \mathrm{New}$ Zealand rabbits (15 males and 15 females) previously fixed in 10\% formaldehyde were studied by dissection. The obturator nerves were originated from the ventral spinal branches of L6 and L7 in $63.3 \%$ of the cases, L5 and L6 in 13.4\%, only L7 in 13.4\%, L7 and S1 in $6.6 \%$ and of L6, L7 and $\mathrm{S} 1$ in $3.3 \%$. The spinal segment that most contributed to the formation of the nerve was L7 $(86.6 \%$ of the nerves). The obturator nerves emitted in all the specimens, a variable number of branches for the internal obturator, external obturator, pectineum, adductor and gracilis muscles. No significant differences were observed between the frequencies of the origin and muscular branches of the obturator nerves when comparing sex and antimers.
\end{abstract}

Keywords: animal anatomy; lagomorphs; lumbosacral plexus; nervous system; Oryctolagus cuniculus

\section{Resumo}

Coelhos da raça Nova Zelândia são amplamente usados como modelos experimentais e representam uma parcela importante dos atendimentos em consultórios veterinários. A conformação músculoesquelética dos coelhos torna frequente a ocorrência de lesões lombossacrais com comprometimento neural. Visando contribuir para a anatomia comparada e no entendimento destas lesões, foram estudadas por dissecção a origem e a distribuição dos nervos obturatórios de 30 cadáveres de coelhos da raça Nova Zelândia (15 machos e 15 fêmeas) fixados previamente em formaldeído a $10 \%$. O nervo obturatório formou-se a partir dos ramos ventrais de L6 e L7 em 63,3\% dos casos, de L5 e L6 em 13,4\%, apenas de L 7 em 13,4\%, de L7 e S1 em 6,6\% e de L6, L7 e S1 em 3,3\%. O segmento espinhal que mais contribuiu para a formação do nervo foi L7 (86,6\% dos nervos). Os nervos obturatórios emitiram em todos os animais, número variável de ramos para os músculos obturador interno, 
obturador externo, pectíneo, adutor e grácil. Não foram observadas diferenças significativas entre as frequências da origem e de ramos musculares dos nervos obturatórios quando comparados sexo e antímeros.

Palavras-chave: anatomia animal, lagomorfos, Oryctolagus cuniculus, plexo lombossacral, sistema nervoso.

Received on: October, 14th, 2018.

Accepted on: May, 20th, 2019.

\section{Introduction}

The nerves supply the hind limb, the caudal and lateral abdomen, and partly the sublombar muscles originate in the lumbosacral plexus. The lumbosacral plexus is formed from the ventral branches of the last three lumbar and the first two or three sacral nerves, depending on the species. It can be divided into the lumbar plexus and the sacral plexus ${ }^{(1)}$.

In domestic mammals, the obturator nerve is usually formed from the junction of the ventral spinal branches of the 4th, 5th, and 6th lumbar nerves (L4, L5, and L6), and is responsible for the innervation of the internal and external obturator, pectineus, adductor, and gracilis muscles ${ }^{(2)}$.

The rabbit's lumbosacral region is prone to injury due to its fragile skeleton and powerful, welldeveloped hindquarter muscles ${ }^{(3)}$. Rabbits have several advantages as laboratory species. White New Zealand rabbits are recently being used in a variety of experiments, including neuronal anesthetic block $^{(4)}$, vascularized nerve grafts ${ }^{(5)}$, orthopedic surgery ${ }^{(6)}$, and neuronal lesions ${ }^{(7)}$. Concomitantly, their popularity as pets is also increasing ${ }^{(8)}$. Therefore, the detailed information about the lumbosacral region and its vertebrae, spinal cord, and nerve roots are assumed to improve the quality of veterinary services; however, few data are available, in particular, regarding these aspects ${ }^{(9)}$.

In mammals, the innervation of pelvic and perineal regions occurs from the lumbosacral spinal cord, and the nerve fibers reach their target by the pelvic and pudendal nerves ${ }^{(10)}$. The obturator nerve may be damaged during the pelvic surgeries and parturition, adversely affecting both pelvic and hind limb functions ${ }^{(2)}$.

Female rabbits have been used to investigate the contribution of pelvic and perineal muscles on the control of micturition, as well as in the understanding of the multiparity impact on the pelvic musculature ${ }^{(11,12)}$; however, knowledge regarding the innervations of the pelvic and perineal regions remains unclear.

This study aimed to characterize the origin and the number of branches of the obturator nerve in the New Zealand rabbits.

\section{Material and methods}

In total 30 rabbits, 15 males and 15 females, aged approximately 1 year, were used. All animals were used in the practical surgery classes and were then donated to the animal anatomy section after being euthanized, according to the protocol 23083.002379/2007-08 approved by the research 
ethics committee of Rio de Janeiro Federal Rural University (UFRRJ). The cadavers were washed and identified by a numbered plastic label attached to the common calcaneal tendon. With the aid of a metal tape, the rostrum-sacral length of each animal was measured from the tip of the nose to the base of the tail. The cadavers were then placed in the lateral recumbent position in order to access the thoracic portion of the aorta, through an incision made between the sixth to the tenth intercostal spaces. Aorta was cannulated with the urethral catheter (number $8 \mathrm{G}$ or $10 \mathrm{G}$ ) and tied with a string to prevent the overflow and to maintain the intravascular pressure. The fixation was obtained by injecting a $10 \%$ formaldehyde solution. Thereafter, the cadavers were immersed in a low-density polyethylene box, comprising the same solution in order to conclude the fixation process.

For inspecting the origins of both the right and left obturator nerves, a longitudinal incision was made at the ventral midline, from the xiphoid process of the sternum to the caudal border of the pelvic symphysis, and, from this, two other vertical incisions were made: one on each antimere until it reached the dorsal midline. Thereafter, the pelvic symphysis was dislocated through the longitudinal section, thus reaching the pelvic cavity and removing its viscera. After removing the adipose tissue and dissecting the psoas muscles, the ventral spinal branches of the lumbar and sacral nerves of both antimeres were observed, for the origin and muscle branches of both the right and left obturator nerves.

To analyze the distributions of the muscular branches of the obturator nerves that emerge in each antimere, we performed a circular incision in the skin of the middle third of the leg and a vertical incision in the skin of the medial side of the thigh, extending from the level of the acetabulum to the first incision in the leg. In sequence, we circumvented the skin of the root of the tail, anus, and external genitalia, and then folded it dorsally the entire segment of the skin and subcutaneous fascia in the gluteal regions, of the thigh and leg. Schematic drawings and photographic documentation were carried out.

Simple absolute and percentage frequencies of the branches that led to the obturator nerve in both sexes and antimeres as well as the frequency of branches of the obturator nerve that were directed to the muscles of the right and left antimeres in both sexes, were calculated. The data for the muscular branches of the obturator nerve were presented as mean \pm standard error. The Kolmorogov-Smirnov (KS) test was used to evaluate the normality of each variable's distribution. Statistical analysis was performed using the Mann-Whitney test with significance of $\mathrm{p}<0.05$.

To check whether the distribution of the observed frequencies for the 30 animals examined agreed with the theory, we applied the chi-square test, at a significance level of $5 \%$, to test the null hypotheses stating that the origins of the nerves do not depend on the gender or antimere.

\section{Results}

The most common origin to the obturator nerve was from the ventral branches of L6 and L7 (63.3\%); however, it also originated from L5 and L6 (13.4\%), L7 (13.4\%), L7 and S1 (6.6\%), and L6, L7, and S1 (3.3\%) (Figs. 1 and 2). The origins of the obturator nerves did not significantly differ between the genders. No cases of antimeric asymmetries were observed regarding the nerve origin. Considering all the 60 nerves dissected, an average of 1.9 ventral branches formed each obturator nerve. The ventral branch of L7 contributed to the obturator nerve formation in $86.6 \%$ of the cases; L6 was present in $80.0 \%$, L5 in $13.4 \%$, whereas S1 contributed to only three male nerves (10.0\%) (Fig. 3). 


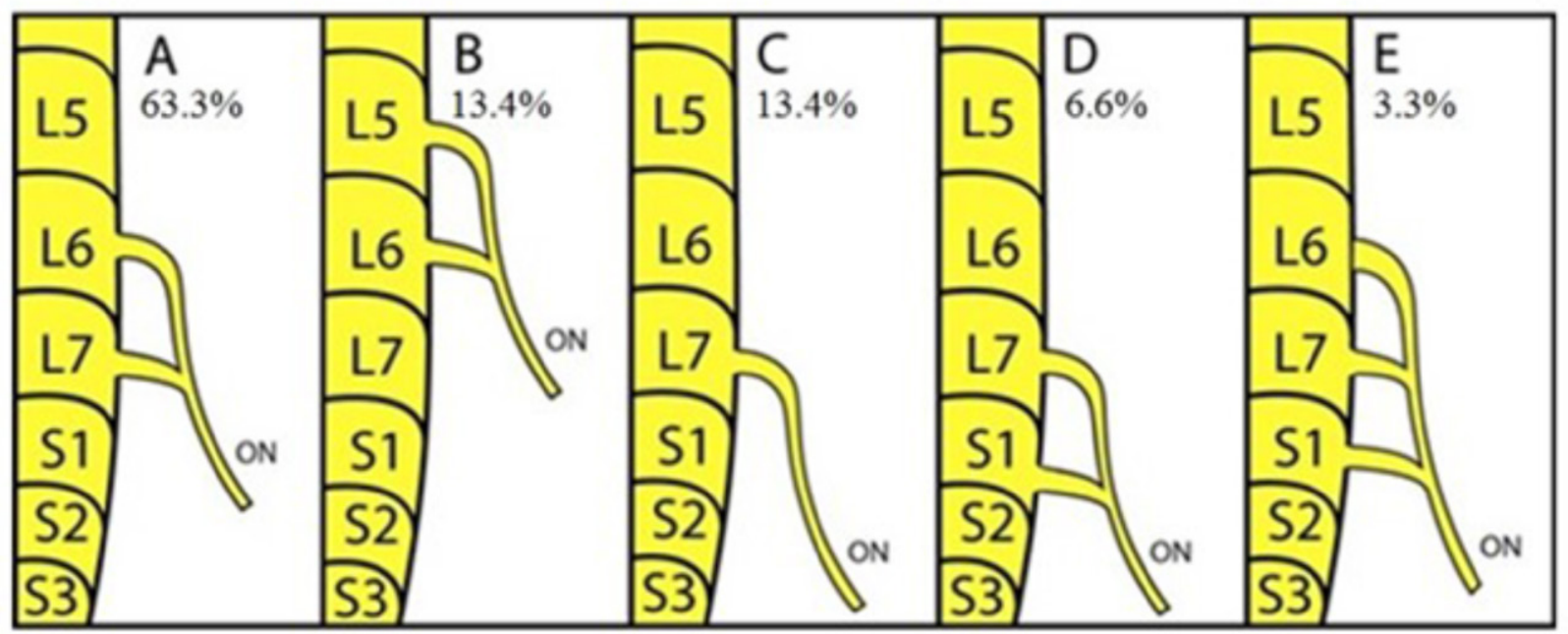

Figure 1. Schematic representation of the five different possible origins (A-E) in the ventral spinal branches (L5-S3) for the obturator nerves $(\mathbf{O N})$ in the New Zealand rabbits $(n=30)$ and the respective percentage frequency.

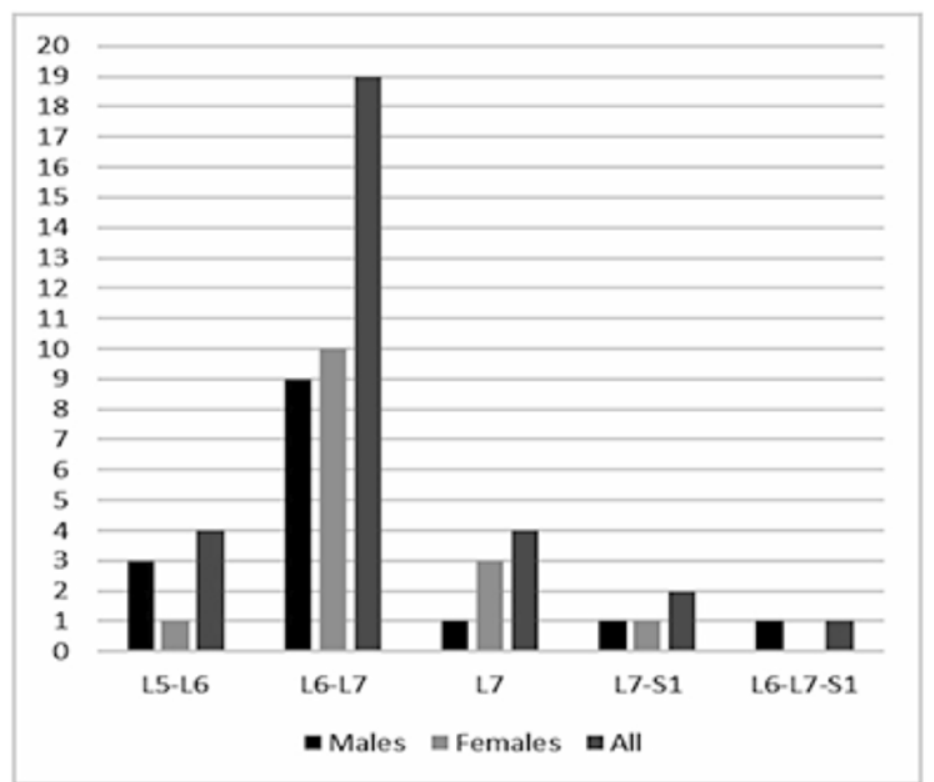

Figure 2. Frequencies of the obturator nerve's origins in the New Zealand rabbits $(n=30)$, separated by male $(n=15)$ and female $(n=15)$ individuals. 


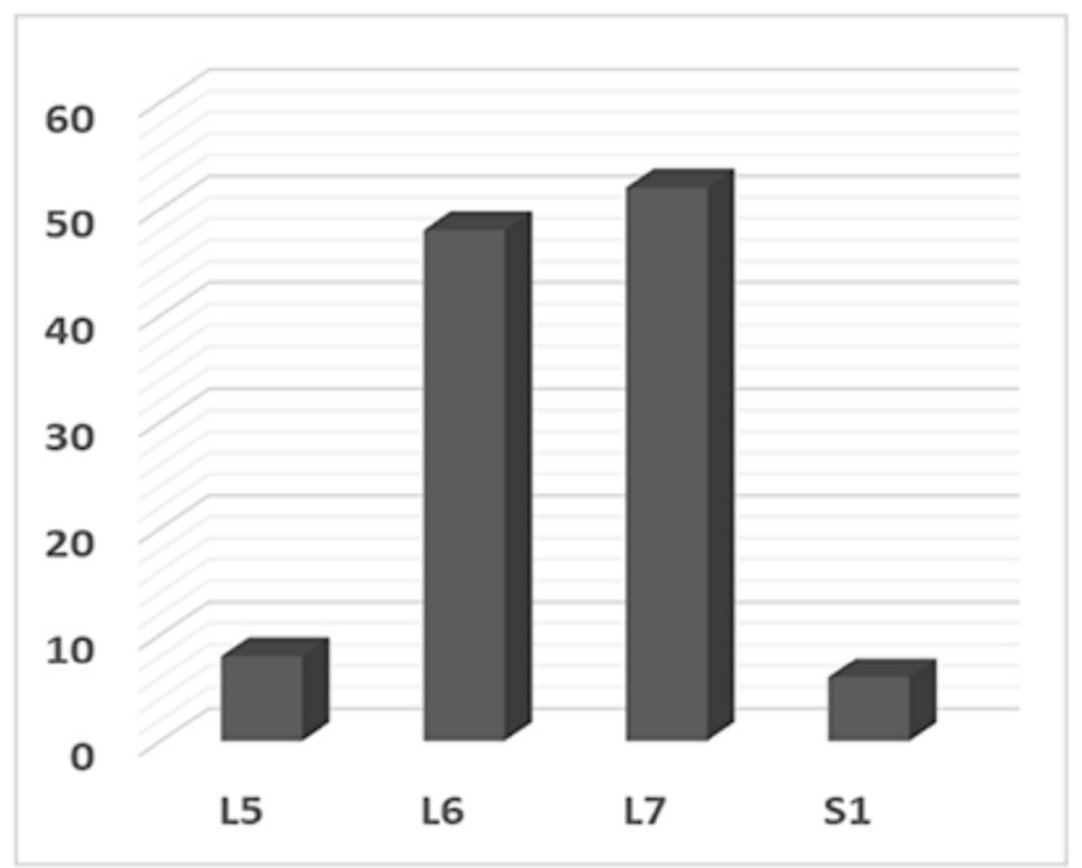

Figure 3. Contributions of each spinal segment in the formation of the obturator nerves $(n=60)$ in the New Zealand rabbits.

On originating, the obturator nerve ventrally crossed the psoas minor muscle through the pelvic cavity and obturator foramen to provide numerous muscular branches to the internal obturator, external obturator, pectineus, adductor, and gracilis muscles (Table 1 and Figure 5). In the lumbosacral plexus, the obturator nerve was caudal to the femoral nerve and cranial to the ischiatic nerve (Fig. 4). No significant differences were observed between the frequencies of origin of the obturator nerves in relation to sex and antimeres (Fig. 6).

Table 1. Absolute (AF) and percentage (PF) frequencies of the number of branches of the obturator nerve to the muscles, separated by the antimeres (R: right; L: left), in the New Zealand rabbits $(n=30)$

\begin{tabular}{ccccccccccc}
\hline Muscles & \multicolumn{2}{c}{ Internal obturator } & \multicolumn{2}{c}{ External obturator } & \multicolumn{2}{c}{ Pectineus } & \multicolumn{2}{c}{ Adductor } & & \multicolumn{2}{c}{ Gracilis } \\
\hline Antimers & $\mathbf{R}$ & $\mathbf{L}$ & $\mathbf{R}$ & $\mathbf{L}$ & $\mathbf{R}$ & $\mathbf{L}$ & $\mathbf{R}$ & $\mathbf{L}$ & $\mathbf{R}$ & $\mathbf{L}$ \\
\hline $\begin{array}{c}\text { Number of } \\
\text { branches }\end{array}$ & $\mathbf{A F} / \mathbf{P F} \%$ & $\mathbf{A F} / \mathbf{P F} \%$ & $\mathbf{A F} / \mathbf{P F} \%$ & $\mathbf{A F} / \mathbf{P F} \%$ & $\mathbf{A F} / \mathbf{P F} \%$ & $\mathbf{A F} / \mathbf{P F} \%$ & $\mathbf{A F} / \mathbf{P F} \%$ & $\mathbf{A F} / \mathbf{P F} \%$ & $\mathbf{A F} / \mathbf{P F} \%$ & $\mathbf{A F} / \mathbf{P F} \%$ \\
\hline Absent & $23 / 76.7 \%$ & $18 / 60.0 \%$ & $16 / 53.3 \%$ & $16 / 53.3 \%$ & $08 / 26.6 \%$ & $09 / 30.0 \%$ & $05 / 16.7 \%$ & $05 / 16.7 \%$ & $03 / 10.0 \%$ & $03 / 10.0 \%$ \\
1 & $07 / 23.3 \%$ & $12 / 40.0 \%$ & $13 / 43.3 \%$ & $12 / 40.0 \%$ & $20 / 66.7 \%$ & $18 / 60.0 \%$ & $18 / 60.0 \%$ & $23 / 76.7 \%$ & $23 / 76.7 \%$ & $25 / 83.3 \%$ \\
2 & - & - & $01 / 3,4 \%$ & $02 / 6.7 \%$ & $02 / 6.7 \%$ & $03 / 10.0 \%$ & $05 / 16.7 \%$ & $02 / 6.6 \%$ & $03 / 10.0 \%$ & $02 / 6.7 \%$ \\
3 & - & - & - & - & - & - & $02 / 6.6 \%$ & - & $01 / 3.3 \%$ & - \\
\hline
\end{tabular}




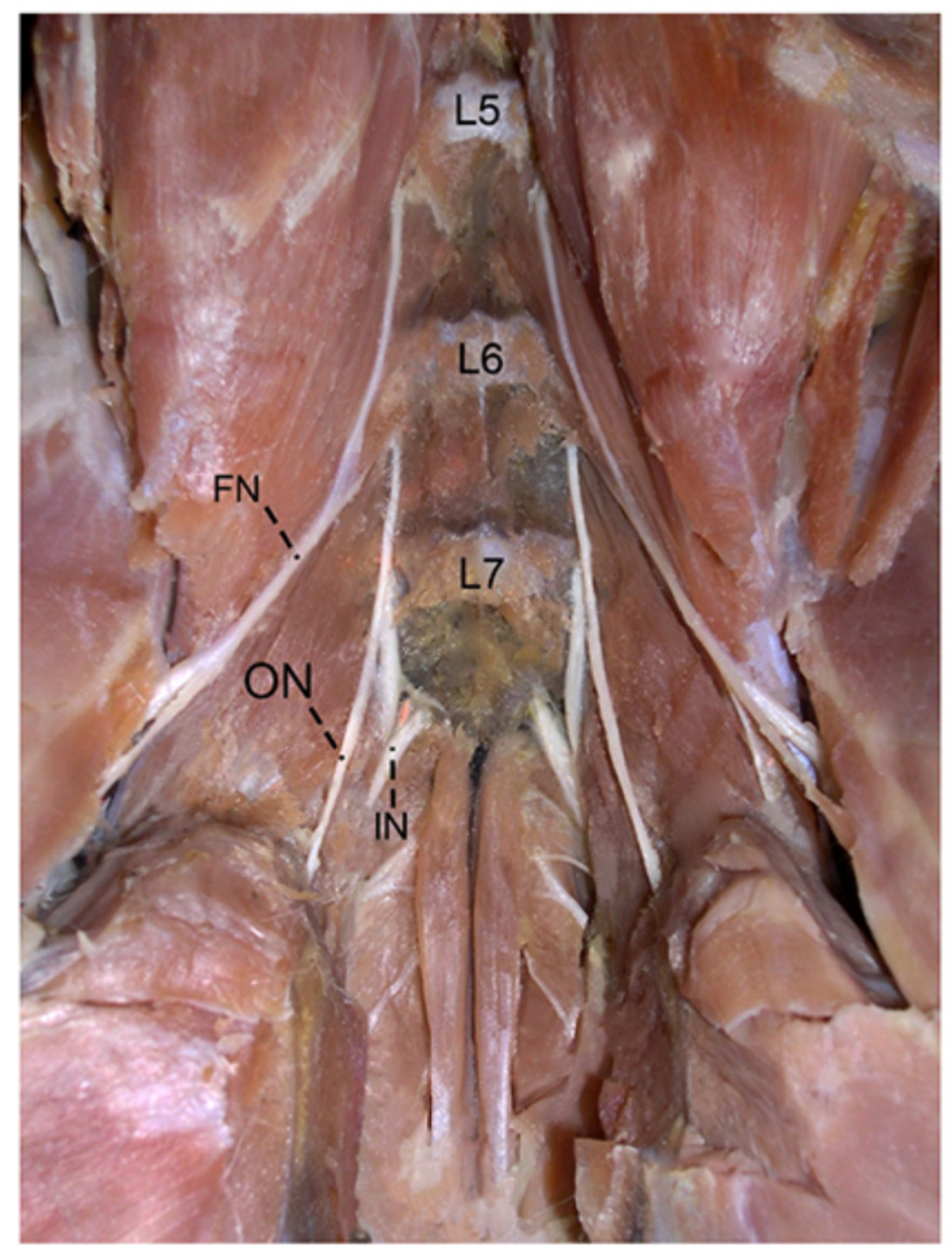

Figure 4. Photomacrograph of the dissected sublombar area of an adult male New Zealand rabbit. ON: obturator nerve; FN: femoral nerve; IN: ischiatic nerve; L5: fifth lumbar vertebra; L6: sixth lumbar vertebra; L7: seventh lumbar vertebra. 


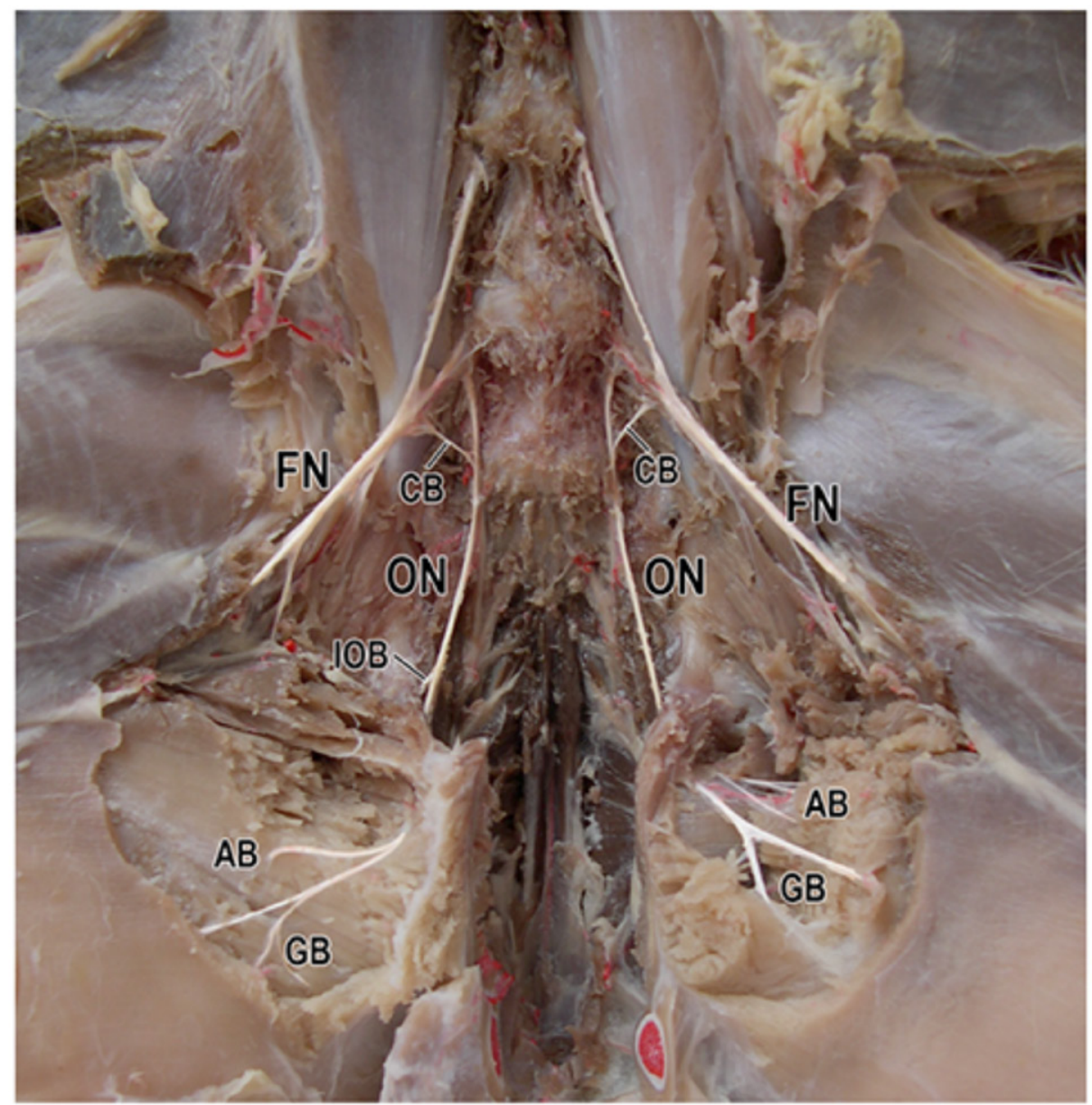

Figure 5. Photomacrograph of the dissected sublombar area of an adult male New Zealand rabbit. ON: obturator nerve; FN: femoral nerve; $\mathrm{CB}$ : communicating branches; IOB: internal obturator branch; $\mathrm{AB}$ : adductor branch; GB: gracilis branch.
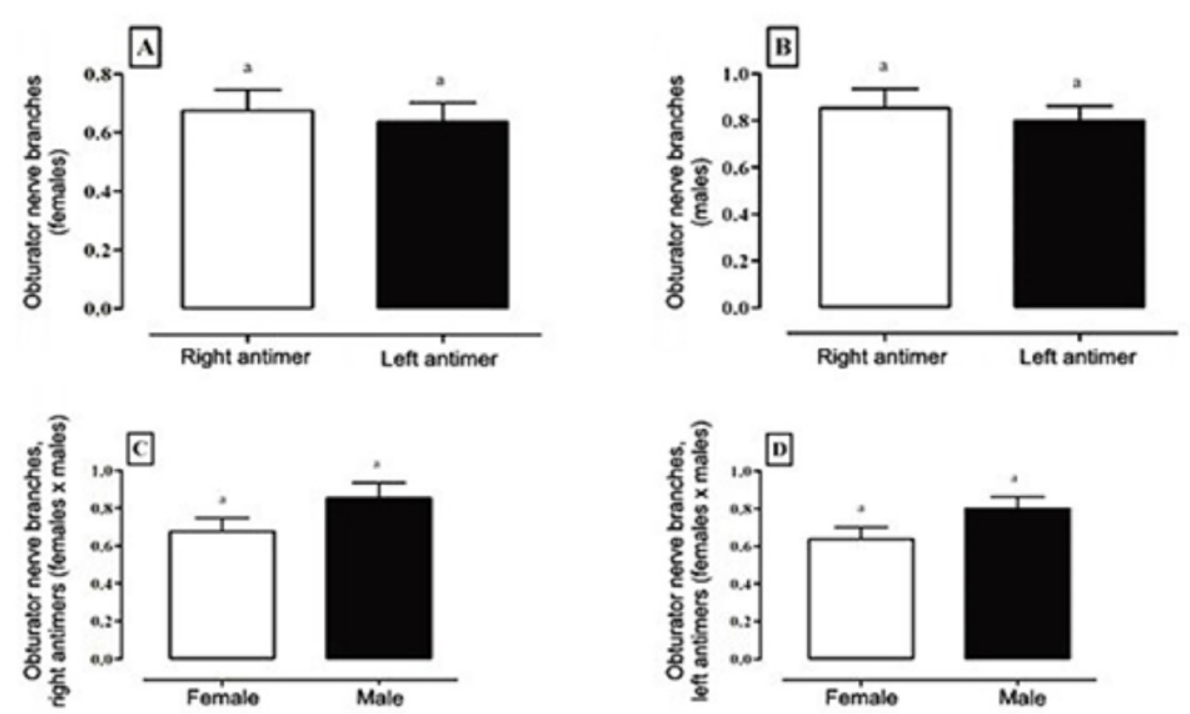

Figure 6. Graphical comparisons between the number of branches of the obturator nerves grouped by the antimeres (A and B) and genders (C and D). The same letter over the columns indicates the absence of significant differences between the compared characteristics. 


\section{Discussion}

The obturator nerve of the New Zealand rabbits majorly comprised two ventral spinal branches, L6 and L7. This finding is also in accordance to the rabbit description by Greenaway et al. ${ }^{(9)}$; however, it differs from that of Harkness and Wagner ${ }^{(13)}$, who reported that the obturator nerves are formed from L5 and L6. In our sample, the origin from L5 and L6 occurred only in 13.4\% of the rabbits (three males and one female). According to Greenaway et al. ${ }^{(9)}$, the formation from L5 and L6 was restricted to few rabbits that revealed only six lumbar vertebrae (an axial skeletal variation). This was not the case of our sample because all the rabbits had seven lumbar vertebrae and the origin in both L5 and L6 can be regarded as a neural variation. No reports are available regarding the sex or antimeric differences in the origin of the obturator nerves in rabbits or in any other mammal species.

The ventral spinal branch of L7 was the most common contributor to the obturator nerve in our sample of New Zealand rabbits. The lumbosacral region of rabbits is more susceptible to trauma at the seventh lumbar vertebra (L7), usually caused by a sudden unsupported movement of the powerful musculature of the hind limbs ${ }^{(9)}$. This might result in a severe injury to the spinal cord and nerve roots. Based on the anatomical origin, this type of trauma almost invariably will affect the obturator nerve. This data may be applicable, for example, during the physical examination of rabbits maintained as pets.

Anatomical studies about the lumbosacral plexus of Lagomorpha order are still scarce; however, descriptive reports of the obturator nerve origins in Rodentia, a closer phylogenetical order, are available for several species. Lacerda et al. ${ }^{(14)}$ observed that in Kerodon rupestris, the lumbar vertebrae ranged from six to seven. Therefore, the obturator nerves arose from the ventral spinal branches of L4, L5, and L6 in the animals with six lumbar vertebrae and from L5, L6, and L7 in those with seven lumbar vertebrae. These results are partially in accordance with the present investigation, where the highest frequencies were observed from the ventral spinal branches of L6 and L7 in both sexes, although the number of lumbar vertebrae remained the same.

In Cuniculus paca, Tonini et al. ${ }^{(15)}$ observed that the obturator nerve originated from the ventral spinal branches from L5 and L6 in 12.5\% of the animals, only L6 in 62.5\%, and L6 and L7 in 25\% of the animals studied. In contrast to our findings in the rabbits, where most of the obturator nerves were formed at least by two ventral spinal branches, in C. paca, most of the obturator nerves were formed from a single branch (L6).

In laboratory rats, the obturator nerve was formed from L2, L3, and L4 ${ }^{(16)}$, which was partially similar to another muridae, Meriones unguiculatus, since its major origin was from L3 and L4 ${ }^{(17)}$. In Galea spixii, the origin was from ventral spinal branches of L5 and L6 for the majority of the specimens ${ }^{(18)}$. In Chinchilla lanigera, the obturator nerve originated from L4 and L5 ${ }^{(19)}$. In Hystrix cristata, the obturator nerve obligatorily originated from the ventral spinal branches of L2 and L3, mostly with contributions from T15 and L1 ${ }^{(20)}$. In Sciurus vulgaris, the same author observed that the obturator nerves originated variably from the ventral spinal branches of L4, L5, and L6 ${ }^{(21)}$. In Dasyprocta leporine, the major origin was from L5, L6, and L7; however, they also originated from L5 and L6 or L6 and L7 in few specimens ${ }^{(22)}$.

The contribution of the ventral spinal branch of L7 to the origin of the obturator nerve, which was the most common $(83.3 \%)$ in the New Zealand rabbits of the present study, was rarely described in rodents. The exception include $25 \%$ of the $C$. paca analyzed by Tonini et al. ${ }^{(15)}$ and $83.3 \%$ of the D. leporina dissected by Oliveira et al. ${ }^{(22)}$. Notably, the contribution of the ventral spinal branch of 
S1, which occurred in only $10 \%$ of the obturator nerves in this study, was not previously reported for lagomorph's or rodent's species. Presumably, the rabbits may have a more caudal origin for the obturator nerves than some other phylogenetically closer species.

In the Carnivora order, in species that possess seven lumbar vertebrae, the obturator nerve is originated from L6 and L7 in the domestic cat ${ }^{(23)}$; solely from L5 in the Leopardus pardalis ${ }^{(24)}$; mainly from L4, L5, and L6 in domestic dogs ${ }^{(25)}$; and from L5, L6, and S1 in both Cerdocyon thous and Lycalopex gymnocercus ${ }^{(26)}$.

In its path, the obturator nerve left the pelvic cavity through the obturator foramen to symmetrically supply the adductor, pectineus, gracillis, and the internal and external obturator muscles, as well as

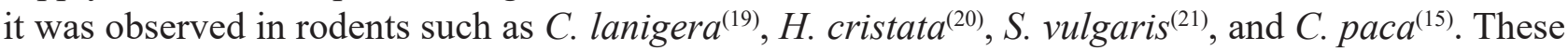
innervated muscles are similar in certain carnivores ${ }^{(23-25)}$. Each of these muscles received one branch, in average, from the obturator nerve, with a slight tendency for the adductor and gracillis muscles to get more than one branch. Perhaps, these two muscles reveal a greater motor relevance to the pelvic limbs than the obturator muscles, which indicate a more constitutive position in the pelvic cavity.

\section{Conclusions}

Comparatively, we concluded that most of the New Zealand rabbits tend to exhibit a slightly caudal origin of the obturator nerve when compared with the other mammals. Even the species phylogenetically close to the rabbits or those with seven lumbar vertebrae tend to exhibit a more cranial origin for the obturator nerve, which rarely includes L7 as the main segment. The contribution of the ventral spinal branch of L7 in nearly all rabbits makes the obturator nerves particularly predisposed to injuries due to the high incidence of trauma in L7 vertebra in this species. The motor innervation is directed to the muscles that act as adductors, similar to a majority of species. These data may be important both for research and veterinary care of rabbits.

\section{Acknowledgments}

This study was financed in part by National Council of Technological and Scientific Development (CNPq), Rio de Janeiro Research Foundation (FAPERJ),Coordination of Improvement for Higher Academic Staff (CAPES) Finance Code 001 and by the Academic Development Program in Research (PDA) of Federal University of Pampa.

\section{References}

1. Konig HE, Liebich HG. Anatomia dos Animais Domésticos: Texto e Atlas Colorido. 6thed. Porto Alegre: Artmed, 2016. 824p. Portuguese

2. Dyce KM, Sack WO, Wensing CJG. Tratado de anatomia veterinária. 4th ed. Rio de Janeiro: Guanabara Koogan; 2010. 840p. Portuguese.

3. Baxter JS. Posterior paralysis in the rabbit. Journal of Small Animal Practice. 1975;16:267-71. https://doi. org/10.1111/j.1748-5827.1975.tb05743.x 
4. Helal SM, Eskandr AM, Gaballah KM, Gaarour IS. Effects of perineural administration of dexmedetomidine in combination with bupivacaine in a femoral-sciatic nerve block. Saudi journal of anaesthesia. 2016;10(1):1824. https://doi.org/10.4103/1658-354X.169469

5. Donzelli R, Capone C, Sgulò FG, Mariniello G, Maiuri F. Vascularized nerve grafts: an experimental study. Neurological research. 2016;38(8):669-677. https://doi.org/10.1080/01616412.2016.1198527

6. Kluge K, Larenza Menzies MP, Kloeppel H, Pearce SG, Bettschart-Wolfensberger R, Kutter AP. Femoral and sciatic nerve blockades and incision site infiltration in rabbits undergoing stifle joint arthrotomy. Laboratory Animal Science Association. 2017;51(1):54-64. https://doi.org/10.1177/0023677215622734

7. Wu W, Niu Y, Kong X, Liu D, Long X, Shu S, Su X, Wang B, Liu X, Ma Y, Wang L. Application of diffusion tensor imaging in quantitatively monitoring chronic constriction injury of rabbit sciatic nerves: correlation with histological and functional changes. The British Journal of Radiology. 2018;91(1083):20170414. http:// dx.doi.org/10.1259/bjr.20170414

8. Susan S, Walshaw S. Rabbits. In: Laber-Laird K, Swindle MM, Flecknell P. Handbook of rodent and rabbit medicine. 1st ed. Tarrytown: Pergamon. 1996.300p.

9. Greenaway JB, Partlow GD, Gonsholt NL, Fisher KR. Anatomy of the lumbosacral spinal cord in rabbits. Journal of the American Animal Hospital Association. 2001;37(1):27-34. https://doi.org/10.5326/15473317$\underline{37-1-27}$

10. Pastelin CF, Juarez R, Damaser MS. Neural pathways of somatic and visceral reflexes of the external urethral sphincter in female rats. The Journal of Comparative Neurology. 2012;520(14):3120-3134. https:// doi.org/10.1002/cne.23079

11. Lopez-Garcia K, Cuevas E, Corona-Quintanilla DL, Jimenez-Estrada I, Martínez-Gomez M, Castelán F. Effect of multiparity on morphometry and oestrogen receptor expression of pelvic and perineal striated muscles in rabbits: is serum oestradiol relevant? European Journal of Obstetrics and Gynecology and Reproductive Biology.2013;169(1):113-120. https://doi.org/10.1016/j.ejogrb.2013.03.032

12. Corona-Quintanilla DL, Lopez-Juarez R, Zempoalteca R, Cuevas E, Castelán F, Martínez-Gómez M.. Anatomic and functional properties of bulboglandularis striated muscle support its contribution as sphincter in female rabbit micturition. Neurourology and urodynamics. 2016;35(6):689-695. https://doi.org/10.1002/ nau. 22788

13. Harkness JE, Wagner JE. The biology and medicine of rabbits and rodents. 3rd ed. Philadelphia: Lea \& Febiger, 1989. 372p.

14. Lacerda PMO, Moura CEB, Miglino MA, Oliveira MF, Albuquerque JFG. Origin of lumbar sacral plexus of rock cavy (Kerodon rupestris). Brazilian Journal of Veterinary Research and Animal Science. 2006;43(5):620628. Available from: http://www.revistas.usp.br/bjvras/article/viewFile/26570/28353

15. Tonini MGO, Sasahara THC, Leal LM, Machado MRF. Origem e distribuição do plexo lombossacral da paca (Cuniculus paca, Linnaeus 1766). Biotemas. 2014;27(2):157-62. http://dx.doi.org/10.5007/2175$\underline{7925.2014 \mathrm{v} 27 \mathrm{n} 2 \mathrm{p} 157}$

16. Vejsada R, Hnik P. Radicular innervation of hind-limb muscles of the rat. Physiologia Bohemoslovaca. 1980;29(5):385-392. https://www.ncbi.nlm.nih.gov/pubmed/6449708

17. Araújo-Júnior H, Oliveira G, Silva-Costa H, Santos A, Viana D, Paula V, Moura C, Oliveira M. Lumbosacral plexus of the mongolian gerbil (Meriones unguiculatus Milne-Edwards, 1867). Bioscience Journal. 2016;32(3):713-720. http://dx.doi.org/10.14393/BJ-v32n3a2016-33117

18. Oliveira GB, Albuquerque JFG, Oliveira MF, Rodrigues MN, Sousa RS, Sousa ES, Miglino MA. 
Source and distribution of the lumbosacral plexus in spix's yellow-toothed cavy (Galea spixii spixii). Journal of Morphological Science. 2008;25(1-4):1-34. http://s3.amazonaws.com/host-article-assets/ jms/587cb47f7f8c9d0d058b46e8/fulltext.pdf

19. Martinez-Pereira MA, Rickes EM. The spinal nerves that constitute the lumbosacral plexus and their distribution in the chinchilla. South African Veterinarian Association. 2011;82(3):150-154. https://www.ncbi. nlm.nih.gov/pubmed/22332298

20. Aydin A. The dissemination of pelvic limb nerves originating from the lumbosacral plexus in the porcupine (Hystrix cristata). Veterinarni Medicina. 2009;54(7):333-339. https://doi.org/10.17221/95/2009-VETMED

21. Aydin A. The spinal nerves that constitute the plexus lumbosacrales of the red squirrel (Sciurus vulgaris). Veterinarni Medicina. 2010;55(4):183-186. https://doi.org/10.17221/3021-VETMED

22. Oliveira GB, Araújo-Júnior HN, Lopes PMA, Costa HS, Oliveira REM, Moura CBE, Paula VV, Oliveira MF. The lumbosacral plexus of the red-rumped agouti (Dasyprocta leporina Linnaeus, 1758) (Rodentia: Caviidae). Semina: Ciências Agrárias, 2016;37(6):4085-4096. http://dx.doi.org/10.5433/1679-0359.2016v37n6p4085

23. Ghoshal NG. Sistema nervoso do carnívoro: nervos espinhais. In: Getty R. Sisson/Grossman Anatomia dos Animais Domésticos. 5th ed. Rio de Janeiro: Guanabara Koogan; 1986. p. 1595-1617. Portuguese.

24. Lopes JA, Fé LCM, Lima AR, Pereira LC, Branco E. Morfologia do plexo lombossacral da jaguatirica (Leopardus pardalis). Biotemas. 2012;25(4):215-220 https://doi.org/10.5007/2175-7925.2012v25n4p215

25. Evans HE, DeLahunta A. Miller's Anatomy of the Dog. 4th ed. Philadelphia: Saunders Elsevier; 2013. $872 \mathrm{p}$.

26. Lorenzão CJ, Zimpel AV, Novakoski E, da Silva AA, Martinez-Pereira MA. Comparison of the Lumbosacral Plexus Nerves Formation in Pampas Fox (Pseudalopex gymnocercus) and Crab-Eating Fox (Cerdocyon thous) in Relationship to Plexus Model in Dogs. The Anatomical Records. 2016;299(3):361-369. https://doi. org/10.1002/ar.23304 